\title{
Major Salivary Gland Cancer pT4b TNM
} Finding v6

National Cancer Institute

\section{Source}

National Cancer Institute. Major Salivary Gland Cancer pT 4b TNM Finding v6. NCI

Thesaurus. Code C65085.

Major salivary gland cancer with tumor invading the skull base and/or pterygoid plates and/or encasing the carotid artery. (from AJCC 6th Ed.) 